\title{
Tachinid (Diptera) parasitoids of Hyphantria cunea (Lepidoptera: Arctiidae) in its native North America and in Europe and Asia - a literature review
}

\author{
Gregory T. Sullivan \& Sebahat K. Ozman-Sullivan
}

Sullivan, G. T. \& Ozman-Sullivan, S. K. 2012: Tachinid (Diptera) parasitoids of Hyphantria cunea (Lepidoptera: Arctiidae) in its native North America and in Europe and Asia - a literature review. — Entomol. Fennica 23: 181-192.

The polyphagous pest fall webworm, Hyphantria cunea (Drury), from North America has invaded at least 20 European, 2 Eurasian (Russia and Turkey) and 10 Asian countries since 1940. At least 54 species of tachinids (Diptera: Tachinidae) from 3 subfamilies, 10 tribes and 30 genera parasitise it. Forty six $(85 \%)$ of the species are from the subfamily Exoristinae, and 17, 12 and 10 species are from 3 of its tribes, Goniini, Eryciini and Exoristini, respectively. Twenty eight of the 54 species are from 7 of the 30 genera: Exorista Meigen (7), Panzeria RobineauDesvoidy (4), Blondelia Robineau-Desvoidy (4), Carcelia Robineau-Desvoidy (4), Hyphantrophaga Townsend (3), Lespesia Robineau-Desvoidy (3) and Zenillia Robineau-Desvoidy (3). The majority of the 30 genera either deposit microtype eggs that are consumed by the host or oviposit on the host.

G. T. Sullivan, Ondokuz Mayis University, OYDEM, 55139 Samsun, Turkey; Email:gsullivan@omu.edu.tr

S. K. Ozman-Sullivan, Ondokuz Mayis University, Faculty of Agriculture, Department of Plant Protection, 55139 Samsun, Turkey; E-mail: sozman@ omu.edu.tr

Received 9 December 2011, accepted 13 March 2012

\section{Introduction}

Human activity has expanded the natural range of a great number of plant pests. Across the globe, those exotic pests, including the fall webworm Hyphantria cunea (Drury) (Lepidoptera: Arctiidae), have collectively inflicted massive economic and social costs in their new environments. According to Warren and Tadic (1967), the development of rapid transport systems that can quickly move passengers, equipment and merchandise around the world undoubtedly contributed to the spread of this extremely polyphagous, foliar-feeding pest that is native to Can- ada, Mexico and the United States of America (USA).

This review documents parasitism of $H$. cunea by tachinids (Diptera: Tachinidae) across its original and expanded ranges from 1891 to 2011. The areas covered include its emergence as a pest; original distribution and expansion of range; and a short overview of tachinid ecology, taxonomy and distribution, as well as tabulation and referencing of parasitoid species, including the names from the original references, ovipositional strategies and parasitism percentages. It also covers the distribution of parasitoids, classical biological control attempts, host-parasitoid 
ecology in new environments and prospects for future interaction between $H$. cunea and tachinids.

The authors have reported on the ichneumonid, chalcidoid and tachinid parasitoids of $\mathrm{H}$. $\mathrm{Cu}$ nea in the Carsamba-Terme district of the Samsun region of Turkey where it is an important pest in hazelnut plantations (Sullivan et al. 2010, 2011, 2012), and considered that it would be useful to investigate its tachinid parasitoids across its full tricontinental range. To the authors' knowledge, the only earlier attempt was by Warren and Tadic (1967), as a part of their review of all parasitoids of this pest.

\section{Review and discussion}

In an enlightening account of the history of the fall webworm in the USA and Canada, Baird (1917) reported that the first record was from specimens collected near New York in about 1770. It was described by Drury (1773) as Phalanea cunea Drury. Baird (1917) further reported that it had been recorded as a "very destructive pest" for the first time in 1797 in the southern American state of Georgia.

The fall webworm first arrived in Europe via Hungary in 1940 and rapidly expanded its range into Austria, Bulgaria, the former Czechoslovakia, Poland, Romania, the former Soviet Union and the former Yugoslavia (Nonveiller 1951, Warren \& Tadic 1970, Szalay-Marzsó 1972). According to Kiritani and Morimoto (2004) it was first seen in Japan in 1945 and Niimura (1949) reported it from Tokyo in 1948. In 1958, it appeared in Seoul, South Korea, and spread rapidly, causing serious damage (Woo 1961). It was first seen in the European part of Turkey in 1975 and rapidly spread to its Black Sea coast in Asia (İren 1977). In 1979, it was first reported in China where it has attacked most cultivated plants in infested areas, particularly ornamentals, planted forests and fruit trees (Yang et al. 2008). Warren and Tadic (1970) reported that across its range it feeds on more than 630 plant species and is among the most polyphagous insects. In addition to its polyphagy, the polyvoltinism and ecological flexibility of $H$. cunea are major barriers to its control (Varjas \& Sehnal 1973).
Hyphantria cunea has now been reported from at least 20 countries in western, southern and eastern Europe, including France (d'Aguilar \& Riom 1979, Moussion \& Gravaud 1987), Greece (Mouloudis et al. 1980), Italy (Montermini \& Oliva 1984, Deseo et al. 1986); 2 in Eurasia, Turkey (İren 1977) and Russia (Sharov \& Izhevskiy 1987); and 10 in Asia, including China (Shi 1981), Azerbaijan (Nurieva 2002), Mongolia and Uzbekistan (Grichanov \& Ovsyannikova 2003), Iran (Rezaei et al. 2003), Kazakhstan and Kyrgyzstan (Anonymous 2005) and Georgia (Japoshvili et al. 2006).

The family Tachinidae, commonly referred to as tachinids, is one of the most diverse dipteran families, with approximately 10,000 described species worldwide (Irwin et al. 2003, O'Hara 2009), about 1,550 species in the Palaearctic region (Herting \& Dely-Draskovits 1993) and close to 880 species in Europe (Tschorsnig et al. 2005). The tachinids are found in nearly all terrestrial environments across the world, including deserts, forests, grasslands, mountains and tundra (Crosskey 1976). Stireman and Singer (2003a, b) and Stireman et al. (2006) reported on many aspects of tachinid research, including phylogeny, geographic diversity and ecology. The great breadth of host use across 11 orders (principally 6 orders) by the family is accompanied by broad host ranges in some tachinid species (Stireman et al. 2006). Obligate endoparasitism of arthropods is common to all tachinids (Pape 1992), and their predominant role as parasitoids of the larval stage of Lepidoptera and other major groups of herbivorous insects ensures they play a major role in limiting herbivore populations and in structuring natural and managed communities (Stireman et al. 2006).

Warren and Tadic (1967) reported 27 tachinid species from $H$. cunea, with 16, 11 and 3 species from North America, Europe and Asia, respectively, including a small degree of overlap. The current review includes their species and those of many other authors. All species names were updated, according to Arnaud (1978), Herting (1984), Wood (1987), Tschorsnig and Herting (1994), Tschorsnig and Richter (1998), O’Hara (2002, 2009, 2010), Kara and Tschorsnig (2003), Tschorsnig et al. (2005), Shima (2006), and Cerretti and Tschorsnig (2010). 
Across its entire natural and expanded range, 54 species of tachinids from 30 genera, 10 tribes and 3 subfamilies have been reported from the fall webworm (Table 1). These totals assume at least 2 species of Winthemia Robineau-Desvoidy in North America (Arnaud 1978) and 2 unidentified Exorista species in South Korea (Kim et al. 1968a). Twenty three, 20 and 17 tachinid species are reported from North America, Asia and Europe, respectively, with a minor overlap of species. In its expanded range of Europe and Asia, the fall webworm hosts a minimum of 32 species. This means there are now more species attacking it in its expanded range than in its native range.

Overall, the number of reported species has increased from 27 (Warren \& Tadic 1967) to 54, and genera from 12 (Warren \& Tadic 1967) to 30 (Table 1). Forty six $(85 \%)$ of the 54 species are from the Subfamily Exoristinae and 17, 12 and 10 species are from its tribes Goniini, Eryciini and Exoristini, respectively. Collectively, the 39 species from these three tribes account for $72 \%$ of the listed species.

Sheehan (1994) and Stireman and Singer (2003a) reported that host species having abundant, gregarious and host plant generalist caterpillars are attacked by considerably more tachinid species than host species with rare, specialist and solitary caterpillars. Stireman and Singer (2003a) further reported that more tachinid species attack hairy caterpillars than smooth ones. In addition, Jeffries and Lawton (1984) found a positive relationship between tachinid diversity and both gregariousness and shelter building. Since the larvae of $H$. cunea are abundant, gregarious, hairy, host plant generalist and shelter building, they fulfill five criteria for vulnerability to attack (Jeffries \& Lawton 1984, Sheehan 1994, Stireman \& Singer 2003a). The 54 species listed for $H$. cunea in this review attest to that vulnerability.

Hyphantria cunea is parasitised by multiple species within some genera. The most prominent examples are Exorista Meigen (7), Panzeria Robineau-Desvoidy (4), Blondelia RobineauDesvoidy (4), Carcelia Robineau-Desvoidy (4), Hyphantrophaga Townsend (3), Lespesia Robineau-Desvoidy (3) and Zenillia RobineauDesvoidy (3) (Table 1). Twenty eight (52\%) of the 54 listed species are from these 7 genera (Table 1).
The almost ubiquitous Compsilura concinnata (Meigen) is common to Europe, Asia and North America (introduced), and Bessa parallela (Meigen), Exorista larvarum (Linnaeus), Pales pavida (Meigen) and Zenillia libatrix (Panzer) are common to Europe and Asia. Compsilura concinnata, E. larvarum and $P$. pavida, which all have a broad host range (Arnaud 1978, Boettner et al. 2000, Strazanac et al. 2001), have been reported from at least 13, 9 and 8 countries, respectively. In contrast, there are single reports of 16 species listed in Table 1.

Tachinids have 2 major ovipositional strategies - direct and indirect. The overall total of 6 strategies includes direct oviposition (4 strategies) that is external or internal and further subdivided by ovolarvipary and ovipary, and also indirect ovipositon (2 strategies) featuring ovolarvipary or the deposition of microtype eggs that are ingested during feeding (Stireman et al. 2006).

The tachinids reported from $H$. cunea in its original range in North America, which is in the Nearctic region, employ 5 of the 6 ovipositional strategies, with the exception being direct internal (unincubated egg) oviposition. Of the 11 North American genera, 6 oviposit indirectly, 3 genera are from the Tribe Goniini (microtype eggs) and 3 are from the Tachininae. Stireman, J. O. (pers. comm., 2012) reported that Tachininae are generally ovolarviparous (e.g. Panzeria) and deposit eggs on substrates frequented by their hosts; the eggs hatch and the larvae wait for passing hosts.

In the expanded range of $H$. cunea in Europe and Asia, which are in the Palaearctic region, representatives from the same 5 subdivisions parasitise $H$. cunea. This review reports 21 genera from those 2 continents, including 10 genera $(48 \%)$ from the tribe Goniini, and 5 genera (24\%) from the tribe Eryciini, which is characterized by direct external oviposition of incubated eggs.

Tachinid species, complexes and rates of parasitism vary widely from site to site, study to study and nation to nation. Nagy et al. (1953) reported from Hungary that up to $62 \%$ of larvae were parasitised by Exorista (as Tachina) larvarum. In contrast, Jermy (1957) reported 10 tachinids from Hungary but cautioned that their life cycles are not synchronised with that of $H$. cunea and that they were unlikely to decisively control outbreaks. From France, d'Aguilar and 
Table 1. Tachinid (Diptera: Tachinidae) parasitoids of Hyphantria cunea (Lepidoptera: Arctiidae) in Asia (A), Europe $(E)$ and North America (NA) listed according to subfamily, tribe, species (alphabetical order) and references (chronological order).

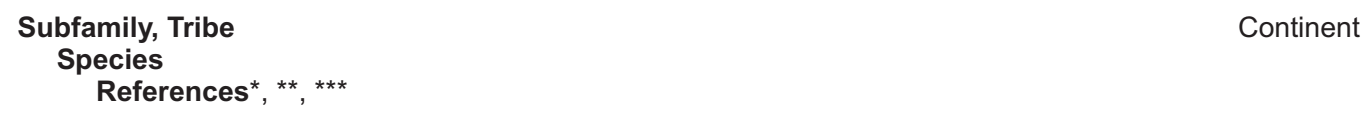

\section{Dexiinae, Voriini}

Thelaira nigripes (Fabricius)

Sharov \& Izhevskiy 1987, Sisojevic \& Cepelák 1987

\section{Exoristinae, Blondeliini}

Blondelia eufitchiae (Townsend)

Swain 1937 as Masicera eufitchiae Town., Warren \& Tadic 1967, Arnaud 1978, O'Hara 2009

Blondelia hyphantriae (Tothill)

Tothill 1922 as Lydella hyphantriae Toth., Schaffner \& Griswold 1934 as Anetia hyphantriae Tothill, Swain 1937 as A. hyphantriae, Swain 1937 as L. hyphantriae, Thompson 1946 as L. hyphantriae, Warren \& Tadic 1967, Arnaud 1978, O'Hara 2009

Blondelia nigripes (Fallen)

Györfi 1954 as Lydella nigripes Fallen

Blondelia obconica (Walker)

Aldrich 1931 as Tachina obconica Walk.

Compsilura concinnata (Meigen)

Tothill 1922, Schaffner \& Griswold 1934, Swain 1937, Thompson 1946, Böhm \& PschornWalcher 1952, Schimitschek 1952, Bogavac 1953, Jermy 1953, Nagy et al. 1953, Sisojevic 1953, Dyadechko 1954, Györfi 1954, Jermy 1957, Szalay-Marzsó 1957, Bogavac 1958, Sikura 1959, Capek 1961, Cepelák 1963, Schimitschek 1964, Tadic \& Kosac 1967, Warren \& Tadic 1967, Tadic 1975, Morris 1976, Arnaud 1978, Riom \& Menassieu 1978, d'Aguilar \& Riom 1979, Trenchev 1980, Baş 1982, Tóth 1985, Allegro 1987, Sharov \& Izhevskiy 1987 , Ziegler 1987, Tóth 1988, Tuncer 1992, Nurieva 2002, Kan et al. 2003, Watanabe 2005, Yang et al. 2008, Cerretti \& Tschorsnig 2010, Sullivan et al. 2012

\section{Exoristinae, Eryciini}

Bactromyia aurulenta (Meigen) Shima 2006

Carcelia bombylans Robineau-Desvoidy Bogavac 1958, Nanni 1991, Cerretti \& Tschorsnig 2010

Carcelia gnava Meigen Kim et al. 1968a

Carcelia protuberans (Aldrich and Webber) Schaffner \& Griswold 1934 as Zenillia protuberans Aldrich \& Webber, Swain 1937 as Z. protuberans, Thompson 1946, Warren \& Tadic 1967, Arnaud 1978, O'Hara 2009

Carcelia sumatrana (Townsend) Shima 2006

Drino inconspicua (Meigen) Bogavac 1953 (misspelled as Drina incospicua), Jermy 1957 as Sturmia inconspicua (Meigen), Bogavac 1958

Drino inconspicuoides (Baranov) Watanabe 2005

Lespesia aletiae (Riley) Webber 1930 as Achaetoneura aletiae (Riley), Schaffner \& Griswold 1934 as A. aletiae, Swain 1937 as A. aletiae, Thompson 1946 as A. aletiae, Warren \& Tadic 1967, Arnaud 1978, Stireman \& Singer 2003b, O'Hara 2009

Lespesia archippivora (Riley) Stireman \& Singer 2003b

Lespesia frenchii (Williston) Webber 1930 as Achaetoneura frenchii (Will.), Schaffner \& Griswold 1934 as A. frenchii, Swain 1937 as $A$. frenchii, Thompson 1946 as $A$. frenchii, Tadic 1963 as $A$. frenchii, Warren \& Tadic 1967, Arnaud 1978, Stireman \& Singer 2003b, O'Hara 2009

Nilea hortulana (Meigen) Takano 1956, Hasegawa 1966, Shima 2006

Senometopia prima (Baranov) 


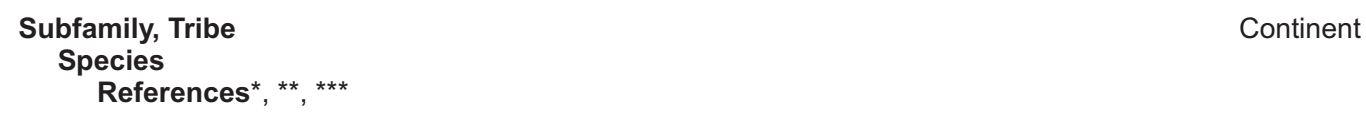

\section{Exoristinae, Exoristini}

Bessa parallela (Meigen)

Sisojevic 1953 as Bessa selecta (Meigen), Jermy 1957 as Ptychomyia selecta Meigen,

Hasegawa 1966 as B. selecta, Tadic \& Kosac 1967 as B. selecta, Sharov \& Izhevskiy 1987, Watanabe 2005, Shima 2006

Chetogena claripennis (Macquart)

Schaffner \& Griswold 1934 as Phorocera claripennis Macq., Swain 1937 as P. claripennis, Thompson 1946 as P. claripennis, Warren \& Tadic 1967 as Euphorocera claripennis (Macq.), Arnaud 1978 as E. claripennis, O'Hara 2009

Chetogena scutellaris (Wulp) Swain 1937 as Phorocera floridensis (Town.), Warren \& Tadic 1967 as Euphorocera floridensis Town., Arnaud 1978, O’Hara 2009

Exorista fasciata Fallen Shu \& Yu 1985

Exorista japonica (Townsend) Kato et al. 1951 as Eutachina japonica Town., Warren \& Tadic 1967 as E. japonica, Kim et al. 1968a as E. japonica, Poong et al. 1981 as E. japonica, Shi 1981, Shu \& Yu 1985, Kan et al. 2003, Watanabe 2005, Yang et al. 2008

Exorista larvarum (Linnaeus)

Böhm \& Pschorn-Walcher 1952, Schimitschek 1952, Bogavac 1953, Jermy 1953, Nagy et al. 1953 as Tachina larvarum L., Sisojevic 1953, Györfi 1954 as T. larvarum, Jermy 1957 as T. larvarum, Szalay-Marzsó 1957, Bogavac 1958, Manolache et al. 1958, Sikura 1959, Schimitschek 1964, Tadic 1975, Tóth 1988, Baş 1982, Allegro 1987, Sharov \& Izhevskiy 1987, Tuncer 1992, Nurieva 2002, Cerretti \& Tschorsnig 2010

Exorista segregata (Rondani) Sisojevic 1953 as Exorista fasciata moreti (Robineau-Desvoidy), Györfi (1954) as Parasetigena segregata Rond., Jermy 1957

Exorista xanthaspis (Wiedemann)

Bogavac 1953 as Exorista fallax Meigen, Nagy et al. 1953 as Tachina fallax Meigen, Sisojevic 1953 as E. fallax, Györfi 1954 as T. fallax, Jermy 1957, Bogavac 1958, Manolache et al. 1958 Trenchev 1980, Sharov \& Izhevskiy 1987 as E. fallax

Exorista sp. (1)

Kim et al. 1968a

Exorista sp. (2)

Kim et al. 1968a

Exoristinae, Goniini

Cadurcia sp. Tadic 1975

Ceromasia auricaudata (Townsend) NA Arnaud 1978, O'Hara 2009

Clemelis pullata (Meigen) Railyan 1974

Eurysthaea scutellaris (Robineau-Desvoidy) E Tadic 1975

Gonia bimaculata (Wiedemann) Bogavac 1953, Herting 1960

Hyphantrophaga blanda (Osten Sacken)

Schaffner \& Griswold 1934 as Zenillia blanda (Osten Sacken), Swain 1937 as Z. blanda, Thompson 1946 as Z. blanda, Warren \& Tadic 1967 as Eusisyropa blanda (Osten Sacken), Morris 1976 as E. blanda, Arnaud 1978 as E. blanda, O'Hara 2009

Hyphantrophaga hyphantriae (Townsend) Townsend 1891 as Meigenia hyphantriae Town., Townsend 1893 as M. hyphantriae, Coquillett 1897, Swain 1937, Warren \& Tadic 1967, Arnaud 1978 as Hyphantrophaga desmiae (Sellers), Stireman \& Singer 2003b, O'Hara 2009

Hyphantrophaga virilis (Aldrich and Webber) Schaffner \& Griswold 1934 as Zenillia virilis Aldrich \& Webber, Swain 1937 as Z. blanda virilis Aldrich \& Webber, Thompson 1946 as Z. virilis, Warren \& Tadic 1967 as Eusisyropa virilis (Aldrich \& Webber), Arnaud 1978 as E. virilis, O'Hara 2009 


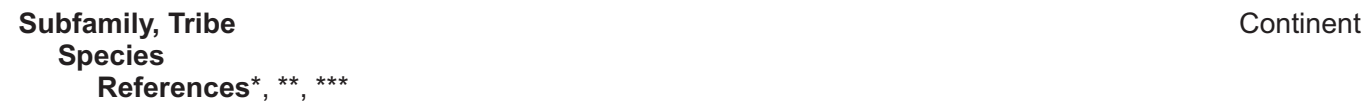

Isoturmia picta (Baranov)

A

Kim et al. 1968a as Sturmia picta Baranoff, Poong et al. 1981 as S. picta

Kuwanimyia conspersa (Townsend) Shima 2006

Pales pavida (Meigen)

Niimura 1951, Bogavac 1953 as Ctenophorocera pavida Meigen, Jermy 1953, Nagy et al. 1953, Sisojevic 1953 as C. pavida, Bogavac 1958, Tadic \& Kosac 1967, Warren \& Tadic 1967, Szalay-Marzsó 1972, Baş 1982, Shu \& Yu 1985 as C. pavida, Sharov \& Izhevskiy 1987 as C. pavida, Tuncer 1992, Richter 1996, Camerini \& Groppali 1999, Hubenov 2001, Watanabe 2005, Cerretti \& Tschorsnig 2010

Patelloa leucaniae (Coquillett) Thompson 1946 as Phorocera leucaniae Coq., Warren \& Tadic 1967, Arnaud 1978, O'Hara 2009

Pseudogonia parisiaca (Robineau-Desvoidy) Anonymous 1997

Sturmia bella (Meigen) Kato et al. 1951, Hasegawa 1966

Zenillia dolosa (Meigen) Watanabe 2005, Shima 2006

Zenillia libatrix (Panzer) Niimura 1951, Jermy 1957, Hasegawa 1966, Warren \& Tadic 1967, Allegro 1987, Shima 2006, Cerretti \& Tschorsnig 2010

Zenillia sp.

Kato et al. 1951, Shima 2006

Exoristinae, Winthemiini

Winthemia spp.

Schaffner \& Griswold 1934, Swain 1937, Arnaud 1978

Tachininae, Ernestiini

Panzeria aldrichi (Townsend)

Swain 1937 as Varichaeta aldrichi Town., Thompson 1946 as Ernestia aldrichi Town., Warren \& Tadic 1967 as Mericia aldrichi (Town.), Wood 1987, O'Hara 2009

Panzeria ampelus (Walker)

Coquillett 1897 as Panzeria radicum (Fabr.), Tothill 1922 as Ernestia ampelus (Walk.), Schaffner \& Griswold 1934 as E. ampelus, Swain 1937 as P. radicum, Swain 1937 as E. ampelus, Swain 1937 as Nemoraea nigricornis Williston, Thompson 1946 as E. ampelus, Tadic 1963 as Mericia ampelus (Walk.), Warren \& Tadic 1967 as M. ampelus, Nordin et al. 1972 as M. ampelus, Morris 1976 as M. ampelus, Arnaud 1978 as M. ampelus, O'Hara 2009

Panzeria arcuata (Tothill) Arnaud 1978 as Mericia arcuata (Tothill), O’Hara 2009

Panzeria johnsoni (Tothill)

Swain 1937 as Ernestia johnsoni Tothill, Thompson 1946 as E. johnsoni, Warren \& Tadic 1967 as Mericia johnsoni (Toth.), Arnaud 1978 as M. johnsoni, O'Hara 2009

Tachininae, Nemoraeini

Nemoraea pellucida (Meigen)

Riom \& Menassieu 1978, d'Aguilar \& Riom 1979, Moussion \& Gravaud 1987, Tiberi \& Bin 1987, Ziegler 1990, Tuncer 1992, Tschorsnig \& Herting 1994, Marchesini et al. 1998, Cerretti \& Tschorsnig 2010, Sullivan et al. 2012

Tachininae, Polideini

Hystricia abrupta (Wiedemann)

Schaffner \& Griswold 1934 as Bombyliopsis abrupta (Wied.), Swain 1937 as B. abrupta, Thompson 1946 as B. abrupta, Warren \& Tadic 1967 as B. abrupta, Arnaud 1978 as B. abrupta, O'Hara 2002, 2009

Tachininae, Tachinini

Archytas aterrimus (Robineau-Desvoidy) Arnaud 1978, O’Hara 2009

A

$A, E$

NA

E

A

A

A, $E$

A

NA

NA

NA

E

NA

NA

* Oliver (1964) reported 4 unnamed species from Louisiana, USA.

** Györfi (1954) reported Exorista rustica but it is a parasitoid of sawflies and is probably a misidentification.

*** Thompson (1946), Arnaud (1978), Shima (2006) and O'Hara (2009) are catalogues and their listings are usually based on the respective original records. 
Riom (1979) reported approximately 30\% parasitism in 1977-1978, with the rate of parasitism of the second generation being higher than in the first because of better synchronisation of the development. However, from the former Yugoslavia, Tadic and Kosac (1967) reported less than $1 \%$ parasitism by tachinids in 1967 . Poong et al. (1981) reported parasitism ranging from $2.4 \%$ to $10.7 \%$ across sites in Korea and that Exorista (Eutachina) japonica (Town) was the most common tachinid. From China, Yang et al. (2008) reported parasitism rates of $4 \%$ to $15.7 \%$ for $E$. japonica and 2\% for C. concinnata. From France, Moussion and Gravaud (1987) reported that Nemoraea pellucida (Meigen) and C. concinnata contributed $84 \%$ and $16 \%$ of tachinid parasitism, respectively, but didn't report the actual percentage of pupae parasitised. From the Samsun region of Turkey, Tuncer (1992) reported tachinid parasitism of $4.2 \%$ and $18 \%$ from overwintered pupae in 1990 and 1991, respectively. Sullivan et al. (2012) reported total parasitism by $N$. pellucida and C. concinnata of overwintered pupae of $1.9 \%$ in 2008 and 4.5\% in 2009 in the Samsun region. They also reported that $N$. pellucida and $C$. concinnata contributed $95 \%$ and $5 \%$, respectively, of total parasitism. Watanabe (2005) reported that the highest percentage parasitism due to a tachinid complex of 6 species in Tsukuba, Japan from 1995-1997 was 70-80\% in third generation larvae in the wandering stage. That report suggests that larvae that leave the web can be highly vulnerable to tachinid attack.

A known parasitoid in one country can be present but not reported as a parasitoid in another country. For example, Carcelia bombylans Robineau-Desvoidy, C. gnava (Meigen), E. larvarum, N. pellucida and Thelaira nigripes (Fabricius) have been reported from Japan but were not listed among the 14 parasitoids of $H$. cunea there (Shima 2006). Those 14 species from Japan and 13 from Hungary (Györfi 1954, Jermy 1957, Szalay-Marzsó 1972) beg the question of whether those numbers reflect exceptional diversity of ecological conditions and/or thorough investigation, or whether there may be under-reporting in other countries. For example, only 3 species have been reported from China (Shi 1981, Shu \& Yu 1985, Yang et al. 2008), 4 species from Turkey (Baş 1982, Çanakcığlu \& Selmi 1988,
Tuncer 1992, Kara \& Tschorsnig 2003, Sullivan et al. 2012), 5 species from South Korea (Kim et al. 1968a) and 7 species from Italy (Cerretti \& Tschorsnig 2010).

Approximately 100 tachinid species have been employed in biological control programs of crop and forest pests, and many of those programs have met with partial or complete success (Hedlund \& Schroder 1981, Grenier 1988). In attempts at classical biological control of $H$. cunea, a number of species were introduced from North America to Europe and Asia. Tadic (1958) reported the introduction of Panzeria (as Mericia) ampelus (Walker) to the former Yugoslavia but noted serious problems with hibernation and the detection of European secondary hosts. Later, Bjegovic (1962) reported an unsuccessful attempt to introduce Lespesia (as Achaetoneura) aletiae (Riley) to the same country. Pupae were placed in an outdoor shelter at $0-10^{\circ} \mathrm{C}$ for overwintering, but all died. Kim et al. (1968b) reported an attempt to introduce $P$. (as Mericia) ampelus to South Korea. It failed because of the asynchronous life cycles of the host and parasitoid, and the lack of alternative hosts when the correct stage of $H$. cunea was not available. Compsilura concinnata was initially introduced into North America in 1906 to combat the exotic forest pest, the gypsy moth, Lymantria dispar Linnaeus (Koch \& Hutchison 2011). Exorista larvarum, Drino disparis Sabrosky and $D$. inconspicua (Meigen) were also introduced for the control of the gypsy moth and they parasitised $H$. cunea in laboratory studies (Hedlund \& Schroder 1981).

However, in the broader context of biological control, it would be remiss of the authors of this review not to mention that, according to Boettner et al. (2000), some introduced tachinids have had catastrophic effects on non-target species. Compsilura concinnata and L. aletiae have broad host ranges (Arnaud 1978, Stireman et al. 2006), and with the benefit of hindsight, they may well be seen as inappropriate choices for biological control programs.

Anecdotal evidence suggests that in the 70 years and 60 years since its accidental introduction into Europe and Asia, respectively, the initial impact of $H$. cunea has been tempered by management and ecological factors, including para- 
sitism by indigenous tachinids. From Hungary, its original entry point to Europe, Ripka, G. (pers. comm., 2011) reported that $H$. cunea usually has a low level pest status in most of the country. Rarely, in certain dry and warm years, the infestation level is higher, generally in private gardens and on street trees. In the Black Sea region of Turkey, local 'hotspots' still occur in the Samsun Region, especially in hazelnut plantations, but the last major outbreak was in 1984-1985. From 2007-2012, there was a much less extensive outbreak in its Carsamba-Terme district. In 2011, 3 generations defoliated hundreds of hectares of hazelnut plantations and fruit trees, including mulberry, a preferred host, and in 2012, the first generation alone defoliated a larger but different area in the same district. According to Warren and Tadic (1967), the generally lower pest status of the fall webworm over time in its expanded range may be partly due to indigenous species coming to prefer it to their native hosts, resulting in a greater degree of life cycle synchronisation and increased specificity of attack.

\section{Closing remarks}

The fall webworm has proven to be a supremely adaptable pest across its natural range in North America and in its greatly expanded European and Asian ranges. Overall, it remains to be seen whether it has reached the limit of its range across the globe. Evidence to the contrary comes from New Zealand where it gained a toehold in the Auckland area in 2003 but it was quickly eradicated (Anonymous 2005). However, the Southern Hemisphere may yet be the scene for future encounters between this extraordinarly resilient pest and endemic tachinids.

Acknowledgements. The considerable assistance of Dr. Hans-Peter Tschorsnig of the State Museum of Natural History in Stuttgart, Germany; Dr. James O'Hara of Agriculture and Agri-Food Canada, Ottawa, Canada; Dr. Hiroshi Shima, formerly of the Biosystematics Laboratory, Graduate School of Social and Cultural Studies, Kyushu University, Fukuoka City, Japan; Dr. John O. Stireman, III, of the Department of Biological Sciences, Wright State University, Dayton, Ohio, USA; Dr. Geza Ripka of the National Food Chain Safety Office, Directorate of Plant Protection, Soil Conservation and Agri-Environment, Budapest, Hungary; Dr. John Goolsby of the
United States Department of Agriculture (Agricultural Research Service) in Weslaco, Texas, USA and Dr Roy Hall of the School of Chemistry and Molecular Biosciences, University of Queensland, Brisbane, Australia, is greatly appreciated by the authors.

\section{References}

Aldrich, J. M. 1931: Notes on Francis Walker's types of North American flies of the family Tachinidae. Proceedings of the United States National Museum No. 2910 80(10): 1-16.

Allegro, G. 1987: Un nemico nuovo per la pioppicoltura italiana: l'Ifantria americana (Hyphantria cunea Drury). — Economia Montana 6: 51-53. [In Italian.]

Anonymous. 1997: Determination list of entomophagous insects Nr. 13. - IOBC/WPRS Bulletin 20(2). 53 pp.

Anonymous. 2005: Global invasive species database. [www document]. URL http://www.issg.org/database/welcome/ (Site visited on 27 June, 2011).

Arnaud, P. H. Jr. 1978: A host-parasite catalog of North American Tachinidae (Diptera). United States Department of Agriculture. - Miscellaneous Publication 1319: 1-860.

d'Aguilar, J. \& Riom, J. 1979: Nemoraea pellucida (Meigen), a new parasite of Hyphantria cunea (Drury). Bulletin de la Societe Entomologique de France 84(7/8): 204-206 [Abstract in The Review of Applied Entomology 1980, 68(8): 3854].

Baird, A. B. 1917: An historical account of the forest tent caterpillar and of the fall webworm in North America. - 47th Annual Report of the Entomological Society of Ontario 73-87.

Baş, R. 1982: Turkiye icin yeni bir bitki zararlisi, Hyphantria cunea (Drury) (Lepidoptera, Arctiidae). - Docentlik Tezi, Istanbul Universitesi Orman Fakultesi, Istanbul. 65 pp. (Not seen; cited by Çanakc1oğlu \& Selmi 1988) [In Turkish.]

Bjegovic, P. 1962: An attempt to introduce the tachinid Achaetoneura aletiae (Riley), a parasite of the fall webworm, from the U.S.A. into Yugoslavia. - Arhiv za Poljoprivredne Nauke i Tehniku 49: 125-131. [In Serbian.]

Boettner, G. H., Elkinton, J. S. \& Boettner, C. J. 2000: Effects of a biological control introduction on three nontarget native species of saturniid moths. - Conservation Biology 14: 798-806.

Bogavac, M. 1953: Some observations of fall webworm parasites. — Zastita Bilja 4(16-17): 58-80. [In SerboCroatian, summary in English.]

Bogavac, M. 1958: Indigenous parasites of Hyphantria cunea and their importance for the population dynamics of this pest. — Zastita Bilja (9)46: 75-81. [In SerboCroatian, summary in English.]

Böhm, H. \& Pschorn-Walcher, H. 1952: Biologie und Bekämpfung von Hyphantria cunea Drury (Lep., Arctiidae-Weißer Bärenspinner). — Pflanzenschutzberichte 9: $105-150$.

Camerini, G. \& Groppali, R. 1999: Predators and parasi- 
toids of Hyphantria cunea in Pavia district (Northern Italy). - Informatore Fitopatologico 49(10): 19-28. [In Italian.]

Çanakcığlu, H. \& Selmi, E. 1988: Turkiye ormanlarinin faydali bocekleri. — Orman Bocek ve Hastaliklariyla Biyolojik Mucadele Semineri, Tebligler, Tarim Orman ve Koyisleri Bakanligi, Orman Genel Mudurlugu, Ankara, No: 670, 27: 85-102. [In Turkish.]

Capek, M. 1961: Verzeichnis der Parasiten, die aus schädlichen Insekten an der Forschungsanstalt der Forstwirtschaft in B. Stiavnica erzogen wurden. Teil II. Wirte der Tachinen, Tachinidae (Diptera). - Vedecké práce Výskumného ústavu lesného hospodárstva vo Zvolene, Banskej Stiav 2: 233-240.

Cepelák, J. 1963: Contribution to the knowledge of the Tachinids of Slovakia (Larvaevoridae-Diptera) II. Biologicke Práce 9: 57-85. [In Slovak.]

Cerretti, P. \& Tschorsnig, H.-P. 2010: Annotated host catalogue for the Tachinidae (Diptera) of Italy. - Stuttgarter Beiträge zur Naturkunde A, N. Ser. 3: 305-340.

Coquillett, D. W. 1897: Revision of the Tachinidae of America North of Mexico, a family of parasitic twowinged insects. - United States Department of Agriculture, Division of Entomology Bulletin Technical Series 7: 1-156.

Crosskey, R. W. 1976: A taxonomic conspectus of the Tachinidae (Diptera) of the Oriental region. - Bulletin of the British Museum (Natural History), Entomology Supplement 26: 1-357.

Deseo, K. V., Montermini, A. \& Cortellini, W. 1986: The first outbreak of the fall webworm (Hyphantria cunea Drury; Lepid., Arctiidae) in North Italy: Preliminary observations on the development, diapause and derivation. - Journal of Applied Entomology 101: 201206.

Drury, D. 1773: Illustrations of natural history. Wherein are exhibited upwards of two hundred and twenty figures of exotic insects, according to their different genera. Vol. 2. - B. White, Horace's Head, London. $90 \mathrm{pp}$.

Dyadechko, N. P. 1954: Parasites and predators of Hyphantria cunea Drury. - Nauchnye Trudy Instituta Entomologii i Fitopatologii Akademii Nauk Ukrainskoi SSR 5: 106-109. [In Russian.]

Grenier, S. 1988: Applied biological control with Tachinid flies (Diptera, Tachinidae): a review. - Anzeiger für Schädlingskunde 61: 49-56.

Grichanov, I. Y. \& Ovsyannikova, E. I. 2003: Interactive agricultural ecological atlas of Russia and neighbouring countries. [www document]. URL http://www. agroatlas.ru/en/content/pests/Hyphantria_cunea/. (Site visited on 27 June, 2011).

Györfi, J. 1954: Hyphantria cunea (Drury). — Erdeszeti Tudomanyos Intezet Evkonyve, Budapest 2: 183198. [In Hungarian.]

Hasegawa, H. 1966: Problems of invading and infesting of the fall web worm, Hyphantria cunea. - Proceedings of Kanto-Tosan Plant Protection Society 13: 5-15. [In Japanese.]

Hedlund, R. \& Schroder, R. F. W. 1981: Parasites: Alter- nate host studies. - In: Doane, C. C. \& McManus, M. L. (eds.), The gypsy moth: research toward integrated pest management. United States Department of Agriculture. Technical Bulletin 1584: 372-375.

Herting, B. 1960: Biologie der westpaläarktischen Raupenfliegen (Dipt., Tachinidae). - Monographien zur angewandten Entomologie 16: 1-188.

Herting, B. 1984: Catalogue of Palearctic Tachinidae (Diptera). — Stuttgarter Beitrage zur Naturkunde. Serie A (Biologie) 369. 228 pp.

Herting, B. \& Dely-Draskovits, A. 1993: Family Tachinidae. - In: Soós, A. \& Papp, L. (eds.), Catalogue of Palaearctic Diptera 13: 118-458. Hungarian Natural History Museum, Budapest. 624 pp.

Hubenov, Z. K. 2001: Addition to the list of hosts of the Bulgarian Tachinidae (Diptera). — Acta Entomologica Bulgarica 7: 51-56. [In Bulgarian.]

İren, Z. 1977: Onemli meyve zararlilari, tanimları, zararlari, yasayislari ve mucadele metodlari. — Zirai Mucadele ve Zirai Karantina Genel Mudurlugu. Ankara Bolge ve Zirai Mucadele Arastirma Enstitusu Yayinlari, Mesleki Eserler Serisi, No. 36, Ankara. 167 pp. [In Turkish.]

Irwin, M. E., Schlinger, E. I. \& Thompson, F. C. 2003: Diptera, true flies. - In: Goodman, S. M. \& Benstead, J. P. (eds.), The natural history of Madagascar: 692702. The University of Chicago Press, Chicago and London. 1728 pp.

Japoshvili, G., Nikolaishvili, A., Dzneladze, N. \& Goguadze, L. 2006: The fall webworm (Hyphantria cunea) in western Georgia. - Proceedings of the Georgian Academy of Science, Biological Series B 4: 122-126.

Jeffries, M. J. \& Lawton, J. H. 1984: Enemy free space and the structure of ecological communities. - Biological Journal of the Linnaen Society 23: 269-286.

Jermy, T. 1953: Über einige raupenfliegen der Hyphantria cunea Drury. - Acta Agronomica Hungarica 3: 2534. [In Hungarian.]

Jermy, T. 1957: Contributions to the knowledge of the tachinids parasitising the larvae of H. cunea. - Annals of the Hungarian Plant Protection Institute 7(195256): 253-262 [Abstract in The Review of Applied Entomology 1959, 47: 4].

Kan, E., Fukuhara, N. \& Hidaka, T. 2003: Parasitism by tachinid parasitoids (Diptera: Tachinidae) in connection with their survival strategy. - Applied Entomology and Zoology 38(1): 131-140.

Kara, K. \& Tschorsnig, H. P. 2003: Host catalogue for the Turkish Tachinidae (Diptera). - Journal of Applied Entomology 127(8): 465-476.

Kato, S., Hatai, N., Iijima, N., Inoue, T. \& Kawasaki, R. 1951: Report on the natural enemies of the fall webworm of Japan in 1950. - Boeki Jiho 22: 7-14. (Not seen; cited by Shima, 2006).

Kim, C. W., Noh, Y. T. \& Kim, J. I. 1968a: Study on the natural enemies proper in Korea attacking fall webworm, Hyphantria cunea Drury. - Entomological Research Bulletin 4: 17-36 [Abstract in The Review of Applied Entomology 1974, 62: 3642].

Kim, C. W., Kim, J. I. \& Kim, S. H. 1968b: Biological con- 
trol of fall webworm, Hyphantria cunea Drury in Korea. II. Studies on the natural enemies imported. Entomological Research Bulletin 4: 37-56 [Abstract in The Review of Applied Entomology 1974, 62: 3642].

Kiritani, K. \& Morimoto, N. 2004: Invasive insect and nematode pests from North America. - Global Environmental Research 8(1): 75-78.

Koch, R. L. \& Hutchison, W. D. 2011: VegEdge, Vegetable IPM resource for the midwest, Compsilura concinnata. [www document]. URL http://www.vegedge.umn.edu/vegpest/beneficials/Comps.htm. (Site visited on 18 October, 2011).

Manolache, F. C., Boguleanu, G. \& Bratu, N. 1958: Contributions a l'étude de la biologie de l'écaille fileuse Hyphantria cunea Drury et des moyens de la combattre. - Analele Institutului de Cercetari Agronomice 25: 623-658.

Marchesini, E., Tosi, L. \& Galbero, G. 1998: Natural enemies of Hyphantria cunea in Veneto. - Informatore Agrario 54: 115-119. [In Italian.]

Montermini, A. \& Oliva, G. 1984: Let's get to know the fall webworm. - Informatore Fitopatologico 34: 3540. [In Italian.]

Morris, R. F. 1976: Relation of mortality caused by parasites to the population density of Hyphantria cunea. The Canadian Entomologist 108: 1291-1294.

Mouloudis, S., Vassilaina-Alexopoulou, P., Papadogeorgopoulos, F. \& Mourikis, P. A. 1980: The presence of Hyphantria cunea (Drury) Lepidoptera: Arctiidae in Greece. - Annales de 1'Institut Phytopathologique Benaki 12(2): 253-255. [Abstract in English.]

Moussion, G. \& Gravaud, A. 1987: The fall webworm (Hyphantria cunea) in southwestern France. - Revue Forestiere Francaise 39(2): 101-106.

Nagy, B., Reichardt, G. \& Ubrizsy, G. 1953: H. cunea in Hungary. — Növényvédelmi Kutató Intézet Kiadványai 1: 70 [Abstract in The Review of Applied Entomology 1956, 44: 137].

Nanni, C. 1991: Activity of indigenous entomophagous species against Hyphantria cunea. - Informatore Fitopatologico 41: 15-21. [In Italian.]

Niimura, T. 1949: Hyphantria cunea Dr. or the fall webworm as a newcomer to Japan. - National Science Museum, Tokyo, Bulletin 25. (Not seen; cited by Warren and Tadic, 1967).

Niimura, T. 1951: On the natural enemies of the fall webworm Hyphantria cunea Dr. - Kontyu 19(1): 31-32. (Not seen; cited by Warren and Tadic, 1967).

Nonveiller, G. 1951: Hyphantria cunea Drury, un nouvel ennemi des cultures en Yougoslavie. — Zastita Bilja 3: 87-95. (Not seen; cited by Warren and Tadic 1967).

Nordin, G. L., Rennels, R. G. \& Maddox, J. V. 1972: Parasites and pathogens of the Fall Webworm in Illinois. — Environmental Entomology 1(3): 351-354.

Nurieva, I. 2002: Bioecological abilities of parasitoids parasitising Hyphantria cunea Drury (Lepidoptera: Arctiidae) in Azerbaijan. — Proceedings of the Fifth Turkish National Congress of Biological Control, 4-7 September 2002, Erzurum, Turkey, 161-166.
O'Hara, J. E. 2002: Revision of the Polideini (Tachinidae) of America north of Mexico. - Studia Dipterologica. Supplement 10. 170 pp.

O'Hara, J. E. 2009: Taxonomic and host catalogue of the Tachinidae of America north of Mexico. [www document]. URL http://www.nadsdiptera.org/Tach/CatNAmer/Home/CatNAmerhom.htm. (Site visited on 18 June, 2010).

O'Hara, J. E. 2010: World genera of the Tachinidae (Diptera) and their regional occurrence. Version 5.0. $74 \mathrm{pp}$. [www document]. URL http://www.nadsdiptera.org/ Tach/Genera/Gentach_ver5.pdf. (Site visited on 20 June, 2010).

Oliver, A. D. 1964: Studies on the biological control of the fall webworm Hyphantria cunea Dr. in Louisiana. Journal of Economic Entomology 57: 192-199.

Pape, T. 1992: Phylogeny of the Tachinidae family-group (Diptera: Calyptratae). — Tijdschrift voor Entomologie 135: 43-86.

Poong, L. H., Kim, O. S. \& Kim, J. T. 1981: Studies on natural enemies parasiting overwintering fall webworm pupae, Hyphantria cunea Drury and way of protection for parasitoids. - Korean Journal of Entomology 11(2): 11-16. [In Korean, summary in English.]

Railyan, N. N. 1974: The fall webworm in Moldavia. Zashchita Rastenii 10: 44-46 [Abstract in The Review of Applied Entomology 1976, 64(10): 5980].

Rezaei, V., Moharramipour, S. \& Talebi, A. A. 2003: The first report of Psychophagus omnivorus (Walker) and Chouioia cunea (Yang) parasitoid wasps of American white webworm Hyphantria cunea Drury (Lep.: Arctiidae) from Iran. - Applied Entomology and Phytopathology 70: 137-138.

Richter, V. A. 1996: On the fauna of tachinids (Diptera, Tachinidae) of the Crimea. - Entomological Review 76: 900-918.

Riom, J. \& Menassieu, P. 1978: Premiers éléments sur le cycle biologique de l'écaille fileuse Hyphantria cunea Drury dans le Sud-Ouest de la France (Lepidoptera, Arctiidae). - Revue de Zoologie Agricole et de Pathologie Vegetale 77: 109-122 [Abstract in Entomological Review 1996, 76: 900-918].

Schaffner, T. V. \& Griswold, C. L. 1934: Macrolepidoptera and their parasites reared from field collections in the northeastern part of the United States. - United States Department of Agriculture, Miscellaneous Publication 188: 1-160.

Schimitschek, E. 1952: Der Amerikanische Webebär Hyphantria cunea Drury in Österreich. - Mitteilungen der Forstlichen Bundes-Versuchsanstalt Wien 48: 929 (Not seen; cited by Schimitschek, 1964).

Schimitschek, E. 1964: Liste der 1934-1936 und 1940 1953 gezogenen parasiten und ihrer wirte. - Zeitschrift fur Angewandte Entomologie 53: 320-341. [In German.]

Sharov, A. A. \& Izhevskiy, S. S. 1987: The parasite complex of the fall webworm Hyphantria cunea Drury (Lepidoptera, Arctiidae) in the European part of the USSR. - Entomologicheskoe Obozrenie 66: 290 
297 [Abstract in Entomological Review 67(1): 4856].

Sheehan, W. 1994: Parasitoid community structure: effects of host abundance, phylogeny, and ecology. In: Hawkins, B. A. \& Sheehan, W. (eds.), Parasitoid community ecology: 90-107. Oxford University Press, New York. 519 pp.

Shi, Y. S. 1981: Exorista japonica - a natural enemy of the fall webworm Hyphantria cunea Drury. - Acta Entomologica Sinica 24: 342. [In Chinese.]

Shima, H. 2006: A host-parasite catalog of Tachinidae (Diptera) of Japan. - Makunagi/Acta Dipterologica Supplement 2. $171 \mathrm{pp}$.

Shu, C. R. \& Yu, C. Y. 1985: An investigation on the natural enemies of Hyphantria cunea. - Natural Enemies of Insects 7: 91-94. [In Chinese.]

Sikura, A. I. 1959: Parasites and predators of Hyphantria cunea Drury in Transkarpatia. - Nauchnye Trudy Ukrainskogo Nauchno-issledovatelskogo Instituta Zaschity Rasteniy 8: 185-198. [In Russian.]

Sisojevic, P. 1953: Exorista fallax Meigen (Dipt., Tachinidae), a parasite of the fall webworm. Preliminary communication on research in 1952. — Zastita Bilja 4(1617): $5-18$.

Sisojevic, P. \& Cepelák, J. 1987: Contribution to the fauna of parasitic flies (Diptera; Tachinidae) of Jakovacki Kljuc (Srem, Northern Serbia). - Proceedings on the Fauna of SR Serbia 4: 117-158. [In Serbian.]

Stireman, J. O. \& Singer, M. S. 2003a: Determinants of parasitoid-host associations: insights from a natural tachinid-lepidopteran community. - Ecology 84: 296310.

Stireman, J. O. \& Singer, M. S. 2003b: What determines host range in parasitoids? An analysis of a tachinid parasitoid community. - Oecologia 135: 629-638.

Stireman, J. O., O'Hara, J. E. \& Wood, D. M. 2006: Tachinidae: Evolution, behavior, and ecology. - Annual Review of Entomology 51: 525-55.

Strazanac, J. S., Plaugher, C. D., Petrice T. R. \& Butler, L. 2001: New Tachinidae (Diptera) host records of eastern North American forest canopy Lepidoptera: baseline data in a Bacillus thuriengiensis variety kurstaki nontarget study. - Journal of Economic Entomology 94: 1128-1134.

Sullivan, G. T., Karaca, I., Ozman-Sullivan, S. K. \& Kolarov, J. 2010: Ichneumonid (Hymenoptera) parasitoids of overwintering Hyphantria cunea (Drury) (Lepidoptera: Arctiidae) in hazelnut plantations of the central Black Sea region of Turkey. - Zootaxa 2608: 63-68.

Sullivan, G. T., Karaca, I., Ozman-Sullivan, S. K. \& Yang, Z. Q. 2011: Chalcidoid parasitoids of overwintered pupae of Hyphantria cunea (Lepidoptera: Arctiidae) in hazelnut plantations of Turkey's central Black Sea region. - The Canadian Entomologist 143(4): 411414.

Sullivan, G. T., Karaca, I., Ozman-Sullivan, S. K. \& Kara, K. 2012: Tachinid (Diptera: Tachinidae) parasitoids of overwintered Hyphantria cunea (Drury) (Lepidoptera: Arctiidae) pupae in hazelnut plantations in Sam- sun province, Turkey. - Journal of the Entomological Research Society 14(1): 21-30.

Swain, R. B. 1937: The parasites of the fall webworm Hyphantria cunea Dr. (Lep.: Arctiidae). - Entomological News 48(9): 244-248.

Szalay-Marzsó, L. 1957: Parasites of Hyphantria cunea found in the Nyirseg Region in the summer of 1954 . Annales Instituti Protectionis Plantarum Hungarici 7: 185-189.

Szalay-Marzsó, L. 1972: Biology and control of the fall webworm (Hyphantria cunea Drury) in the Middleand East European Countries. - Organisation Europeenne et Mediterranneene pour la Protection des Plantes 3: 25-35 [Abstract in The Review of Applied Entomology 1973, 61(3): 702].

Tadic, M. 1958: Biological control of the fall webworm (Hyphantria cunea Dr.) in Europe. - Proceedings of the Tenth International Congress of Entomology, Montreal, Canada, 1956, 4: 855-858.

Tadic, M. 1963: Natural enemies of fall webworm (Hyphantria cunea Dr.) in North America. - Entomophaga 8(4): 245-252.

Tadic, M. 1975: Process of adaption of autochthonous entomophags on the fall webworm (Hyphantria cunea Dr.) in Yugoslavia 1963-1972. - Zastita Bilja 26: 247-265. [In Serbian.]

Tadic, M. \& Kosac, D. 1967: Spread of the fall webworm (Hyphantria cunea Dr.) in the world and in the Balkans and adaptation of autochthonous parasites to this pest. - Zastita Bilja 18: 357-364. [In Serbo-Croatian, summary in English]

Takano, S. 1956: Systematic and ecological studies of Tachinidae. - Annual Report of Cooperative Research of the Ministry of Education in 1955. Agriculture, 5963. (Not seen; cited by Shima, 2006).

Thompson, W. R. 1946: A catalog of the parasites and predators of insect pests, Sec. 1, Part 7, Parasites of the Lepidoptera: 307-309. - Imperial Agriculture Bureaux, Institute of Entomology, Parasite Service, Belleville, Ontario, Canada.

Tiberi, R. \& Bin, F. 1987: Hyphantria cunea (Drury) (Lepidoptera Arctiidae): Controllo naturale da entomofagi indigeni a dieci anni dalla sua introduzione in Nord Italia. - Atti del Convegno Sulle Avversità del Bosco e delle Specie Arboree da Legno, 305-312. [In Italian.]

Tóth, S. 1985: Beiträge zur Kenntnis der Raupenfliegen Parasiten ungarischer Schmetterlingen (Diptera: Tachinidae), I. - Folia Musei Historico-naturalis Bakonyiensis 4: 163-172.

Tóth, S. 1988: Taxonomic and ecological issues of researches on Tachinidae at Sár-hegy (Diptera: Tachinidae). - Folia Historico Naturalia Musei Matraensis, Supplementum 2: 55-62. [In Hungarian.]

Tothill, J. D. 1922: The natural control of the fall webworm (Hyphantria cunea Drury) in Canada together with an account of its several parasites. - Bulletin of the Canadian Department of Agriculture, New Series 3: 1107. 
Townsend, C. H. T. 1891: A parasite of the fall web-worm. — Psyche 6(187): 176-177.

Townsend, C. H. T. 1893: Hosts of North American Tachinidae, I. - Psyche 6(206): 466-468.

Trenchev, G. 1980: Parasite species of subfamily Exoristinae (Diptera, Tachinidae) in Bulgaria. - Rasteniev'd Nauki 17(5): 121-126. [In Bulgarian.]

Tschorsnig, H. P. \& Herting, B. 1994: Die Raupenfliegen (Diptera: Tachinidae) Mitteleuropas: Bestimmungstabellen und angaben zur verbreitung und ökologie der einzelnen arten. — Stuttgarter Beiträge zur Naturkunde (A), 506: 1-170. Online authorized version of English translation by Rayner, R. \& Raper, C.: Tschorsnig, H. P. \& Herting, B. 2001: The Tachinids (Diptera: Tachinidae) of Central Europe: Identification keys for the species and data on distribution and ecology. [www document]. URL http://tachinidae.org.uk/site/downloads.php. (Site visited on 27 May, 2011).

Tschorsnig, H.-P. \& Richter, V. A. 1998: Family Tachinidae. - In: Papp, L. \& Darvas, B. (eds.), Contributions to a manual of Palaearctic Diptera 3: 691-827. Science Herald, Budapest. 880 pp.

Tschorsnig, H.-P., Richter, V. A., Cerretti, P., Zeegers, T., Bergström, C., Vaòhara, J., Van de Weyer, G., Bystrowski, C., Raper, C., Ziegler, J. \& Hubenov, Z. 2005: Tachinidae. - In: Fauna Europaea Service, 1.2. [www document]. URL http://www.faunaeur.org. (Site visited on 15 May, 2011).

Tuncer, C. 1992: Amerikan Beyaz Kelebegi (Hyphantria cunea Drury, Lepidoptera: Arctiidae)'nin Samsun ve cevresindeki biyolojisi ve ozellikle konukcu bitkilerin degisik acilardan etkileri uzerinde arastirmalar. Doktora Tezi, Ankara Universitesi, Fen Bilimleri Enstitusu, Ankara. [In Turkish.]

Varjas, L. \& Sehnal, F. 1973: Use of a juvenile hormone analogue against the fall webworm, Hyphantria $\mathrm{cu}$ nea. - Entomologia Experimentalis et Applicata 16(1): 115-122.
Warren, L. O. \& Tadic, M. 1967: The fall webworm, Hyphantria cunea, its distribution and natural enemies. A world list (Lepidoptera: Arctiidae). - Journal of the Kansas Entomological Society 40(2): 194-202.

Warren, L. O. \& Tadic, M. 1970: The fall webworm, Hyphantria cunea (Drury). - Arkansas Agricultural Experiment Station Bulletin 759: 1-106.

Watanabe, M. 2005: Parasitism and over-wintering status of tachinids (Diptera) on larvae of the fall webworm, Hyphantria cunea Drury (Lepidoptera: Arctiidae), in the Kanto Region of Japan. - Applied Entomology and Zoology 40(2): 293-301.

Webber, R. T. 1930: A revision of the North American tachinid flies of the genus Achaetoneura. - Proceedings of the United States National Museum 78(10): $1-37$.

Woo, K. S. 1961: Studies on Hyphantria cunea Dr., a newly introduced insect pest. - Master's Thesis, Seoul National University, Seoul, Korea. (Not seen; cited by Warren and Tadic, 1967).

Wood, D. M. 1987: Tachinidae. — In: McAlpine, J. F., Peterson, B. V., Shewell, G. E., Teskey, H. J., Vockeroth, J. R. \& Wood, D. M. (eds.), Manual of Nearctic Diptera 2. - Agriculture Canada Monograph 28(110): 1193-1269.

Yang, Z. Q., Wang, X. Y., Wei, J. R., Qu, H. R. \& Qiao, X. R. 2008: Survey of the native insect natural enemies of Hyphantria cunea (Drury) (Lepidoptera: Arctiidae) in China. - Bulletin of Entomological Research 98(3): 293-302.

Ziegler, J. 1987: Zur Kenntnis der Wirtsbeziehungen einheimischer Raupenfliegen (Dipt., Tachinidae). 5. Beitrag. - Entomologische Nachrichten und Berichte 31: 83-84.

Ziegler, J. 1990: Zur Kenntnis der Wirtsbeziehungen paläarktischer Raupenfliegen (Dipt., Tachinidae). 7. Beitrag. - Entomologische Nachrichten und Berichte 34: $140-141$. 